\title{
Impact of key factors on expected development of onshore wind energy sector in Poland and development scenarios
}

\author{
Izabela Wielewska ${ }^{3}$, Karol Tucki ${ }^{1, *}$, Anna Bączyk $^{2}$, and Magda Trzaska ${ }^{1}$ \\ ${ }^{1}$ Warsaw University of Life Sciences, Department of Production Organization and Engineering, Nowoursynowska Street 164, \\ 02-787 Warsaw, Poland \\ ${ }^{2}$ Warsaw University of Life Sciences, Department of Hydraulic Engineering, Nowoursynowska Street 159, 02-776 Warsaw, Poland \\ ${ }^{3}$ UTP University of Science and Technology in Bydgoszcz, Department of Agronomy, Fordońska Street 430, 85-790 Bydgoszcz, Poland
}

\begin{abstract}
The aim of the paper was to analyse the wind power market in Poland by reviewing the factors that shape and influence its current state and the possible development prospects. The paper was focused on legislative, environmental, manufacturing, sociocultural and economic factors. Barriers to the development of onshore wind power market and the expected development of wind energy in Poland in the years 20172020 were identified and measured based on a survey. The review of individual factors and the study performed present that legislative barriers and the introduction of the 'distance act' are factors with the biggest influence on the current stagnation of onshore wind energy sector. A review of the recommendations concerning the distance (from protected areas and housing) required to build wind farms set forth in literature shows that Poland is the only country with such harsh restrictions. With its good environmental conditions and technical capacities, Poland can become a European leader in the production of energy from wind. The only barrier is the legislative environment and political instability on the national level. Without improvements in this sector, there is no chance for new wind projects, as these factors are crucial for development of this type of energy.
\end{abstract}

\section{Introduction}

In the times of gradually diminishing resources of fossil fuels and a growing energy demand, renewable power seems to be a lifebelt for the global economy and the natural environment. Pursuant to directive of the European Parliament and of the Council no. 2009/28/CE [1-4], Poland was obligated to reach at least a $15 \%$ share of energy from renewable sources in gross final consumption of energy. Nevertheless, hard bituminous coal and lignite remain the main sources of energy in Poland, with the respective shares of $50 \%$ and $31.4 \%$ in the overall production of energy [5].

Wind energy is an important factor for Poland in the process of pursuing the EU's objective. Onshore wind power allows to obtain $5824 \mathrm{MW}(69 \%)$ of the total of $8538 \mathrm{MW}$ (as at 30.09.2017) [6] of installed capacity of RES. The economically and environmentally justified share of onshore wind power in the Polish energy market is estimated to amount to $10 \mathrm{GW}$, compared to today's $5.8 \mathrm{GW}$ of installed capacity of onshore wind energy.

The onshore wind energy sector, developing dynamically since 2001 , is now in stagnation caused by the implementation of new and amendments of the currently applicable legal deeds. The biggest of the barriers encountered so far is the Act of 20 May 2016 on investments in wind power stations, commonly known as the 'distance act'. The provisions that are especially important for the sectors apply to:

1) Restrictions concerning distance between wind turbines and occupied buildings/nature conservation areas,

2) Increase of the real property tax base,

3) Identification of wind farm location exclusively based on a local zoning plan.

The tragic situation of wind power is further enhanced by the current condition of the market of green certificates, i.e. negotiable certificates of origin confirming that electrical energy has been produced from renewable energy sources. The scale of oversupply estimated by PSEW (Polish Wind Energy Association) is the largest ever, with the price of green certificates being drastically low $[7,8]$. Trying to minimise or mitigate the problem, the Polish government introduced new amendments to the act on renewable sources of energy. The crucial changes in the renewed Act signed on 14 April 2017 apply to determination of the substitution fee, which now depends on market prices of certificates of origin [9]. Originally established at the level of PLN 300.03 , it is now calculated based on $125 \%$ of the annual average weighted price of property rights in the previous calendar year. The act entered into force without prior consultations, and met with fierce criticism of representatives of the sector [10-15]. All these actions make the achievement of the objective set to Poland

Corresponding author: karol tucki@sggw.pl 
impossible (a 15\% share of energy from renewable sources in gross final consumption of energy) [16-20].

Poland has good wind conditions [21,22], but in order to be able to use them, it needs to create sustainable conditions for its development [23-25], in particular, by introducing stable legislation which is a standard in other countries [26-28].

The aim of the article is to present the current status of wind energy, indicate the significance of key factors for the prospects of its development and choose the most plausible development scenario.

\section{Methodology}

Two research techniques were used to achieve the objectives, i.e.: a survey conducted in February 2017 among employees directly employed in the wind energy field; and analysis, as part of which individual properties and incidents were identified and their relationship with the whole were described. Additionally, the research encompassed an overview of available scientific literature including legal deeds, technical articles, reports and studies. The survey, entitled "Analysis of development of wind energy in Poland", was sent to companies rendering services or delivering products for the purpose of wind energy production. 30 out of the 100 surveys sent were collected. The surveys were filled in by companies specialising in:

- environmental consultancy,

- noise measurements and monitoring for the existent and planned wind farms,

- electric power generation from renewable energy sources and provision of regulatory system services (PGE Energia Odnawialna S.A., a Polish state power company).

Relying on experts' knowledge and the literature available, 23 factors were distinguished with potential significance for the slowdown of wind energy in Poland [29-37]. The factors were divided into 5 groups (table 1) and the division was used as a basis for the Ishikawa diagram [38], with the aim to facilitate expert assessment of individual criteria. The groups of factors listed in table 1 were used as 2nd order objectives. Acting in accordance with the Ishikawa diagram principle, it was assumed that the impact of all groups of factors equals $100 \%$ (same as the impact of individual factors within the group). This principle was applied by the experts, who performed their assessment by breaking the 100\% down into individual factors and showing their significance. The experts assessed the significance of individual factor groups and individual factors in the group [38]. Then, the consensus of expert opinions was analysed [38]. For this purpose, the concordance coefficient $\theta$ was calculated, based on formula (1):

$$
\Theta=\frac{12 S}{N_{E}^{2}\left(b^{3}-b\right)}
$$

where:

$S$ - sum of squares of factual deviations of rank values, $N_{E}$ - number of experts, $b$ - number of factors assessed.
To find out whether the consensus of expert opinions was not accidental, the $\chi^{2}$ criterion was used, expressed by formula (2):

$$
\chi^{2}=\frac{S}{1 / 12 N_{E} b(b+1)-\frac{1}{b-1} \sum_{i-1}^{N_{E}} T_{i}}
$$

where: $T_{i}$ - similar rank coefficient.

If the $\chi^{2}$ value was higher than the tabular value $\chi^{2 t a b}$, and the concordance coefficient differed significantly from zero, the consensus of expert opinions was considered not accidental. Additionally, consensus of opinions was also assessed with the use of the coefficient of variation $\mathrm{V}$, calculated based on formula (3):

$$
V_{j}=\frac{g_{j}}{m_{j}} 100 \%
$$

where: $g_{j}$ - standard deviation, $m_{j}$ - arithmetic mean of expert assessments.

Another method used in the study was the scenario method. The scenarios selected were supposed to facilitate expert assessment of the likelihood of application of individual wind power development prospects for the years 2017-2020. The respondents' task was to break down $100 \%$ of the 1 st order elements into 2nd order factors with potential influence on the emergence and significance of 1 st order barriers. The scenarios were as follows:

- $\quad$ significant cuts in all investments,

- increased number of turbines with less dynamic increase in installed capacities than before, despite the restrictions introduced by the distance act,

- increased number of household installations and offshore wind farms and reduced number of onshore wind farms with tall towers.

\begin{tabular}{|c|c|}
\hline $\begin{array}{c}\text { Parameter } \\
\text { symbol }\end{array}$ & Barriers \\
\hline $\mathrm{C} 21$ & Legal (legislative) barriers \\
\hline $\mathrm{C} 211$ & $\begin{array}{l}\text { Restrictions introduced by legal regulations } \\
\text { concerning the conditions, location and } \\
\text { construction of wind power stations } \\
\text { (including, among others, minimum distance } \\
\text { between the wind power station and residential } \\
\text { properties/combined use buildings/protected } \\
\text { nature/ pilot forest complexes) }\end{array}$ \\
\hline $\mathrm{C} 212$ & $\begin{array}{l}\text { Restrictions imposed by the local zoning plan; } \\
\text { weak laws concerning spatial planning }\end{array}$ \\
\hline $\mathrm{C} 213$ & Stability of state and local government \\
\hline $\mathrm{C} 214$ & $\begin{array}{l}\text { Lack of political motivation to support wind } \\
\text { power; i.e. complicated procedures and long } \\
\text { waiting time for permits required in order to } \\
\text { build wind turbines, inadequate attention paid } \\
\text { in the Polish power strategy and development } \\
\text { concepts to the development of wind power }\end{array}$ \\
\hline $\mathrm{C} 215$ & $\begin{array}{l}\text { Risks connected with the implementation of } \\
\text { bidding system }\end{array}$ \\
\hline
\end{tabular}

Table 1. 1st and 2nd order barriers which may potentially favour the freezing of wind power development in Poland. 
Table 1: continuation.

\begin{tabular}{|c|c|}
\hline $\mathrm{C} 22$ & Economic barriers \\
\hline C221 & $\begin{array}{l}\text { Relatively high costs of production of wind } \\
\text { energy when compared to conventional energy }\end{array}$ \\
\hline $\mathrm{C} 222$ & $\begin{array}{l}\text { High investment costs of implementation of } \\
\text { new technologies that need to be incurred at } \\
\text { the start }\end{array}$ \\
\hline $\mathrm{C} 223$ & $\begin{array}{l}\text { Economic standing of the country (gross } \\
\text { domestic product, inflation, unemployment } \\
\text { rate, etc.) }\end{array}$ \\
\hline $\mathrm{C} 224$ & $\begin{array}{l}\text { Interest rates and availability of credit } \\
\text { facilities }\end{array}$ \\
\hline $\mathrm{C} 225$ & $\begin{array}{l}\text { Inadequate possibilities to obtain subsidies } \\
\text { from EU green funds }\end{array}$ \\
\hline $\mathrm{C} 23$ & Manufacturing and technological barriers \\
\hline $\mathrm{C} 231$ & $\begin{array}{l}\text { Inadequately developed power grid for power } \\
\text { reception from wind devices }\end{array}$ \\
\hline $\mathrm{C} 232$ & Obsolete grid infrastructure \\
\hline $\mathrm{C} 233$ & $\begin{array}{l}\text { Difficulties pertaining to the planning and } \\
\text { prediction of available capacity and volumes } \\
\text { of power produced from wind power stations, } \\
\text { resulting from dependency of the parameters } \\
\text { on meteorological conditions }\end{array}$ \\
\hline $\mathrm{C} 234$ & $\begin{array}{l}\text { Necessity to store some of the power } \\
\text { generated at wind power stations as back-up } \\
\text { power }\end{array}$ \\
\hline $\mathrm{C} 24$ & Sociocultural barriers \\
\hline $\mathrm{C} 241$ & $\begin{array}{l}\text { Conflicts with ecological circles. No methods } \\
\text { to avoid conflicts with ecological circles }\end{array}$ \\
\hline $\mathrm{C} 242$ & $\begin{array}{l}\text { Ecological awareness of the society: wind } \\
\text { power is perceived negatively - conflicts with } \\
\text { local communities }\end{array}$ \\
\hline $\mathrm{C} 243$ & $\begin{array}{l}\text { No interest in employment in wind power } \\
\text { sectors }\end{array}$ \\
\hline $\mathrm{C} 244$ & $\begin{array}{l}\text { Inadequate education on wind power at } \\
\text { schools }\end{array}$ \\
\hline $\mathrm{C} 25$ & Environmental barriers \\
\hline $\mathrm{C} 251$ & $\begin{array}{l}\text { Adverse wind conditions in areas available for } \\
\text { the execution of wind energy projects }\end{array}$ \\
\hline $\mathrm{C} 252$ & $\begin{array}{l}\text { Environmental risks related to wind power } \\
\text { (farms' impact on birds } \\
\text { and bats) }\end{array}$ \\
\hline $\mathrm{C} 253$ & $\begin{array}{l}\text { Hazards to anthropological environment posed } \\
\text { by wind power (noise emission, flicker effect, } \\
\text { shadow cast by turbines, magnetic field } \\
\text { emission, impact on value of the nearby } \\
\text { properties) }\end{array}$ \\
\hline $\mathrm{C} 254$ & $\begin{array}{l}\text { Limited area available to install wind power } \\
\text { stations due to the existence of National Parks, } \\
\text { Nature Reserves, Nature } 2000 \text { Areas, Ramsar } \\
\text { (wetland) Areas, eco-corridors, Landscape } \\
\text { Parks, Protected Landscape Areas, Natural and } \\
\text { Landscape Complexes, ecological sites and } \\
\text { natural monuments }\end{array}$ \\
\hline $\mathrm{C} 255$ & $\begin{array}{l}\text { Negative perception of the impact of wind } \\
\text { power stations on landscape }\end{array}$ \\
\hline
\end{tabular}

\section{Results}

Before the survey results were presented, the Act of 20 May 2016 on investments in wind power stations had been thoroughly analysed, as it has for some time had major impact on the condition of the sector. The document sets forth conditions and requirements of/for location of wind power stations within the vicinity of existent or planned residential premises. The Act introduced major restrictions, in particular, when it comes to minimum distance between wind turbines and occupied buildings and nature conservation areas, and the possibility to choose investment site exclusively based on local zoning plans (LZP). Poland is the only European state with such restrictive distance requirements [39-41]. Figure 1 and table 1 show selected EU states and their regulations concerning the restrictions and recommendations pertaining to distance between wind power stations and residential buildings.

Because of the restrictions introduced, there are currently no investors interested in the performance of new wind farm projects. In addition, all projects which are currently at the procedural stage needed to obtain a building permit have been withheld, which means that huge amounts of money spent on agreements with owners of the lands leased, tests carried out etc., have been lost. The already erected farms and previous investors are afraid that they may go bankrupt because of the raised taxes or decreasing prices of certificates of origin.

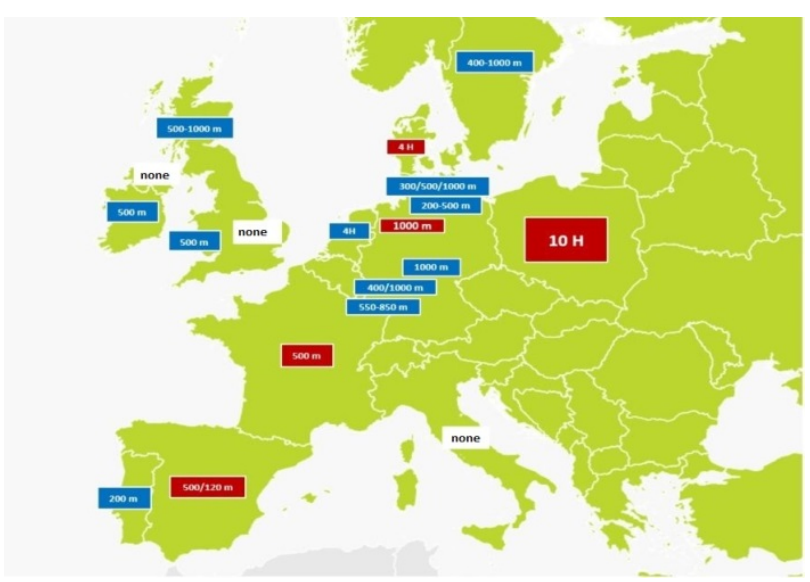

Fig. 1. Minimum distances of wind power stations from residential buildings in selected countries; blue: recommendations, red - requirements [author's own work based on [41].

Table 2. Minimum distances of wind power stations from residential buildings in selected countries [41].

\begin{tabular}{|l|l|}
\hline Country & Distance \\
\hline Poland & $\begin{array}{l}\text { Distance equal to or bigger than ten times the } \\
\text { height of the wind power plant measured from } \\
\text { the ground level to the highest point of the } \\
\text { structure, including technical elements, } \\
\text { such as rotor and blades }\end{array}$ \\
\hline Denmark & $\begin{array}{l}\text { Distance from buildings must be equal to or } \\
\text { bigger than four times the height of the wind } \\
\text { power station; }\end{array}$ \\
$\begin{array}{l}\text { Distance from major roads and railroad rails } \\
\text { must at least be equal to the overall height of the } \\
\text { wind turbine. Additionally, the distance also } \\
\text { depends on the noise level. }\end{array}$ \\
\hline $\begin{array}{l}\text { Recommendations: } \\
\text { Saara: 550-850 m from residential } \\
\text { properties, } \\
\text { Thuringia: 1000 m from residential } \\
\text { properties and recreational or } \\
\text { historical sites, }\end{array}$ \\
\hline
\end{tabular}


Table 2: continuation.

\begin{tabular}{|c|c|}
\hline Germany & $\begin{array}{l}\text { - Rhineland-Palatinate: } \mathbf{4 0 0} \mathbf{m} \text { from } \\
\text { individual detached houses, } 1000 \mathrm{~m} \\
\text { from residential areas, } \\
\text { Bremen: } \mathbf{2 0 0 - 5 0 0} \mathbf{m} \text { from residential } \\
\text { properties, } \\
\text { - Schleswig-Holstein: } \mathbf{3 0 0} \mathbf{m} \text { from areas } \\
\text { with } 1 \text { to } 4 \text { residential properties, 500 } \\
\text { m from rural areas, } \mathbf{1 0 0 0} \mathbf{m} \text { from } \\
\text { cities and holiday resorts. } \\
\text { Legal requirements: } \\
\text { Lower Saxony/Saxony: } 1000 \mathrm{~m} \text { from } \\
\text { residential properties } \\
\text { Hamburg: } \mathbf{3 0 0} \mathbf{m} \text { from individual } \\
\text { residential properties, 500 } \mathbf{m} \text { from } \\
\text { residential areas, } \mathbf{5 0 - 1 0 0} \mathbf{m} \text { from the } \\
\text { nearest roads, railways, telecom } \\
\text { networks, transformers, real estate } \\
\text { boundaries, 200-500 } \mathbf{m} \text { from forests, } \\
\text { wetlands, stand off areas of birds and } \\
\text { bats and other protected areas. }\end{array}$ \\
\hline En & No recommendations or legal requirements. \\
\hline $\mathrm{Scc}$ & $\begin{array}{l}\text { Recommendations: } \\
\text { Area within } \mathbf{2} \mathbf{~ k m} \text { from cities and villages; the } \\
\text { assessment is performed in concreto depending } \\
\text { on geographical conditions and visual factors, } \\
\text { which is why the distance is usually smaller } \\
(\mathbf{5 0 0 - 1 0 0 0} \mathbf{m}) \text {, but can also be extended. } \\
\text { Wind power stations must not be built in the } \\
\text { vicinity of national parks and landscape } \\
\text { parks. }\end{array}$ \\
\hline Wales & $\begin{array}{l}\text { Recommendations: } \\
\text { - } 500 \text { m from houses - the distance may } \\
\text { vary, depending on background noise } \\
\text { measurements and other neighbouring } \\
\text { noise-generating investments. }\end{array}$ \\
\hline Ireland & $\begin{array}{c}\text { Recommendations: } \\
\bullet \quad 500 \mathrm{~m}\end{array}$ \\
\hline $\begin{array}{l}\text { Northern } \\
\text { Ireland }\end{array}$ & $\begin{array}{l}\text { Lack of statutory regulations concerning the } \\
\text { distance. } \\
\text { Recommendations: } \\
\text { - Distance corresponding to the turbine } \\
\text { height from base to the tip of the } \\
\text { blade }+10 \%\end{array}$ \\
\hline Italy & $\begin{array}{l}\text { No generally applicable regulations } \\
\text { concerning the distance. }\end{array}$ \\
\hline Spain & $\begin{array}{l}\text { Distance corresponding to } \mathbf{5 0 0} \mathbf{~ m} \text { from } \\
\text { residential properties, } \mathbf{1 2 0} \mathbf{m} \text { from roads and } \\
\text { power grids. }\end{array}$ \\
\hline Portugal & $\begin{array}{l}\text { Recommendations: } \\
\text { - } \quad \mathbf{2 0 0} \mathbf{~ m} \text { from residential properties }\end{array}$ \\
\hline Sweden & $\begin{array}{c}\text { Recommendations: } \\
\bullet \quad 400-1000 \mathrm{~m}\end{array}$ \\
\hline $\begin{array}{l}\text { The } \\
\text { Netherlands }\end{array}$ & $\begin{array}{l}\text { Recommendations: } \\
\text { - four times the height of the wind } \\
\text { turbine [measured to the hub (tower)] } \\
\text { from the neighbouring buildings }\end{array}$ \\
\hline France & $\mathbf{5 0 0} \mathbf{~ m}$ from residential properties \\
\hline
\end{tabular}

The survey was prepared and presented to respondents 9 months after the effective date of the 'distance act'.

Respondents were of the opinion that the biggest negative impact on the development of wind power in Poland is exerted by legal factors (fig. 2). More than 1/2 of all respondents (62\%), irrespective of seniority and work placement, indicated this factor as the most important [42]. Nearly $1 / 5$ of respondents were of the opinion that the environmental factor plays major role in the development of wind power sector, with further $11 \%$ saying that sociocultural barriers may be significant for the development of wind energy. Only $3 \%$ of respondents considered manufacturing and technological barriers to hinder the growth of wind energy share in the country's power mix.

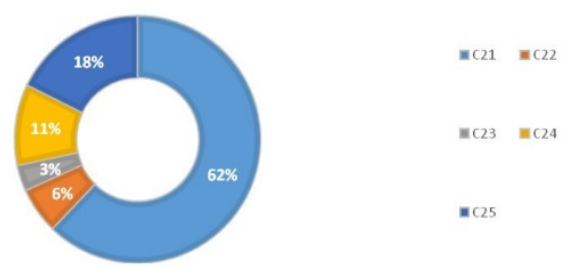

Fig. 2. Significance of 1st order barriers for the development of wind power in Poland.

Respondents indicated that among all legislative barriers, it was the introduction of the distance act that had the biggest impact on the hindered development of all wind projects. Significance of this factor was assessed as $58 \%$. The runner-up to this factor, responsible (in the respondents 'opinion) for the poor condition of the market was (tab. 3) the lack of motivation to support wind power among legislators and complicated administrative procedures, including long waiting time for permits required in order to build wind turbines (18\%), with successive places taken by: restrictions pertaining to poor coverage of the territory of Poland by local zoning plans (11\%), stability of state and local government $(7 \%)$ and risks connected with the implementation of bidding system (6\%).

Table 3. Share of individual barriers in the development of Polish wind power.

\begin{tabular}{|c|c|c|}
\hline $\begin{array}{c}\text { Parameter } \\
\text { symbol }\end{array}$ & Share, \% & $\begin{array}{c}\text { Coefficient } \\
\text { of variability }\end{array}$ \\
\hline \multicolumn{3}{|c|}{$\mathrm{C} 21$} \\
\hline $\mathrm{C} 211$ & 58 & \multirow{5}{*}{1.09} \\
\hline $\mathrm{C} 212$ & 11 & \\
\hline C213 & 7 & \\
\hline $\mathrm{C} 214$ & 18 & \\
\hline $\mathrm{C} 215$ & 6 & \\
\hline \multicolumn{3}{|c|}{$\mathrm{C} 22$} \\
\hline $\mathrm{C} 221$ & 31 & \multirow{5}{*}{1.55} \\
\hline C222 & 36 & \\
\hline C223 & 12 & \\
\hline C224 & 10 & \\
\hline $\mathrm{C} 225$ & 11 & \\
\hline \multicolumn{3}{|c|}{$\mathrm{C} 23$} \\
\hline $\mathrm{C} 231$ & 44 & \multirow{4}{*}{0.59} \\
\hline $\mathrm{C} 232$ & 29 & \\
\hline $\mathrm{C} 233$ & 14 & \\
\hline $\mathrm{C} 234$ & 13 & \\
\hline \multicolumn{3}{|c|}{$\mathrm{C} 24$} \\
\hline $\mathrm{C} 241$ & 36 & \multirow{3}{*}{0.75} \\
\hline $\mathrm{C} 242$ & 45 & \\
\hline C243 & 5 & \\
\hline
\end{tabular}


Table 3: continuation.

\begin{tabular}{|l|c|c|}
\hline $\mathrm{C} 244$ & 14 & \\
\hline \multicolumn{2}{|c|}{$\mathrm{C} 25$} \\
\hline $\mathrm{C} 251$ & 10 & \\
\hline $\mathrm{C} 252$ & 24 \\
\hline $\mathrm{C} 253$ & 15 & \multirow{2}{*}{0.47} \\
\hline $\mathrm{C} 254$ & $\mathbf{3 5}$ & \\
\hline $\mathrm{C} 255$ & 18 & \\
\hline
\end{tabular}

The second most important hazard to onshore wind power indicated by respondents was the environmental factor. The average percentage rate allocated to environmental barriers by respondents equalled 18 . Among the environmental factors, the one related to the limited area available to carry out the investment, due to the presence of various nature conservation forms within a substantial portion of the country's area, was considered the most significant $(35 \%)$. This restriction is closely connected with one of the legal factors, i.e. the requirement that the distance between wind power stations and residential buildings (or nature conservation areas) must not be smaller than 10 times the turbine length. $24 \%$ of respondents also listed the negative impact on birds and bats among the negative environmental effects of wind power stations. Another $18 \%$ were of the opinion that negative perception of the impact of wind power stations on landscape was an important barrier, while further $15 \%$ indicated the hazard to anthropological environment (noise emission, flicker effect, shadow cast by turbines, magnetic field emission, impact on value of the nearby properties). Only $10 \%$ was attributed by respondents to adverse wind conditions in areas available for the execution of wind energy projects. Sociocultural factors, among which are conflicts with local communities and ecological circles, received 11\%, with further $6 \%$ being allocated to economic factors. Among the most significant hazards in 'economic' group, respondents enumerated high initial capital expenditures and relatively high costs of production of wind energy when compared to traditional energy.

In the opinion of respondents, the least important factors with the potentially inhibiting impact on wind energy in Poland were manufacturing and technological factors, which received $3 \%$ of votes. In this field, respondents pointed mainly to the inadequately developed power grid for power reception from wind devices.

Introduction of the act of 20 May 2016 on investments in wind power stations had a substantial limiting effect on the development of wind energy in Poland.

Out of the three scenarios proposed, the majority of respondents chose scenario 1, which stipulated significant cuts in investments in wind power. The likelihood that this option will be selected was assessed as $82 \%$ (tab. 4). $14 \%$ was attributed to scenario 3 , assuming growth in the number of household systems and $5 \%$ to scenario 2 , according to which wind power will keep thriving in Poland despite the distance act, although less dynamically than before. The coefficients analysed show that the consensus of expert opinions is not accidental.
Table 4. Scenarios of wind power development in Poland.

\begin{tabular}{|c|c|c|c|}
\hline \multicolumn{2}{|r|}{ Scenario } & \multirow{2}{*}{$\begin{array}{c}\begin{array}{c}\text { Likelihood, } \\
\%\end{array} \\
\\
\\
80\end{array}$} & \multirow{2}{*}{$\begin{array}{c}\begin{array}{c}\text { Coefficient } \\
\text { of } \\
\text { variability }\end{array} \\
\\
\\
0.55\end{array}$} \\
\hline 1 & $\begin{array}{l}\text { Between } 2017 \text { and } 2020 \text {, } \\
\text { there will be a significant cut } \\
\text { down in investments in wind } \\
\text { power, leading to a material } \\
\text { decrease in the number of } \\
\text { wind turbines, especially } \\
\text { those with high towers. }\end{array}$ & & \\
\hline 2 & $\begin{array}{l}\text { In the years } 2017-2020, \\
\text { despite the restrictions } \\
\text { imposed by the act, the wind } \\
\text { power sector will develop, } \\
\text { which is going to translate } \\
\text { into a bigger number of } \\
\text { turbines, even if the } \\
\text { development will not be as } \\
\text { dynamic as it used to be. }\end{array}$ & 3.33 & 3.55 \\
\hline 3 & $\begin{array}{l}\text { In the years } 2017-2020, \\
\text { despite restrictions imposed } \\
\text { by the distance act, the } \\
\text { number of wind turbines will } \\
\text { grow, but their structure will } \\
\text { change, i.e. turbines with low } \\
\text { towers will outdistance } \\
\text { turbines with tall towers and } \\
\text { the number of offshore } \\
\text { installations will grow. }\end{array}$ & 16.67 & 2.00 \\
\hline \multicolumn{2}{|c|}{ Concordance coefficient } & \multicolumn{2}{|c|}{0.168} \\
\hline \multicolumn{2}{|c|}{ Criterion $\chi^{2}$} & \multicolumn{2}{|c|}{10.067} \\
\hline
\end{tabular}

\section{Conclusions}

Analysis of the wind power market in Poland enabled assessment of the as-is state, the environmental and technical potential and the most plausible development scenario for the sector. Upon a review of factors significant for the past, presence and future of wind energy in Poland, their relevance for the shaping of the wind energy market was established. The following conclusions have been drawn from the study:

1) The review of legislative factors and an own study pointed to legislative barriers, including introduction of the distance act, as the most significant factor responsible for the current stagnation of the onshore wind energy sector. Available readings concerning recommendations and permitted distances between wind farms and residential buildings/nature conservation forms for different countries, show Poland as the only country with such harsh restrictions.

2) In the opinion of respondents, the second most important barriers hindering and preventing increase in the installed capacity of onshore wind power sector are environmental barriers, among which is a factor correlating with the distance act, i.e. limited space available for the installation of wind power stations due to the existence of nature conservation areas.

3) The analysis of sociocultural factors revealed benefits from the development of wind energy, mainly in terms of employment and additional funds for 
communes/municipalities and the economy. In this phase, we found out that offshore wind energy is perceived positively by the local community and that there are no conflicts with fishing environments.

4) The share of individual manufacturing and technological factors demonstrated that barriers such as obsolete grid infrastructure and inadequately developed power grid can be eliminated by projects by PSE (Polish Power Grids) concerning expansion of the national transmission system in terms of power evacuation, connection of new energy generating sources and reconstruction of the central point.

5) Analysis of economic factors confirmed information about the dropping investment and operating costs due to expansion of the power market and technological progress.

6) With reference to the biggest barrier faced by the onshore wind energy sector, the most plausible prospect for the years 2017-2020 is a significant drop inthe number of wind turbines.

Analysis of the resources available and benefits of wind power showed that Poland has good environmental conditions and technical capacities and has the potential to become a European leader in wind power production. The only barrier here is the regulatory environment and political instability on the national level. Without improvements to this end, there is no chance for new wind projects to be implemented, as it is these very factors that make foundations for the development of wind energy.

\section{References}

1. Directive 2009/28/EC of the European Parliament and of the Council of 23 April 2009 on the promotion of the use of energy from renewable sources and amending and subsequently repealing Directives 2001/77/EC and 2003/30/EC.

2. R.L. Arantegui, A. Jäger-Waldau, Photovoltaics and wind status in the European Union after Paris Agreement. Renewable and Sustainable Energy Reviews 81 (2018), 2460-2471

3. C. Wustemeyer, R. Madlener, D.W. Bunn, A stakeholder analysis of divergent supply-chain trends for the European onshore and offshore wind installations. Energy Policy 80 (2015), 36-44

4. O. Ellabban, H. Abu-Rub, F. Blaaljerg, Renewable energy resources: current status, future prospects and their enabling technology. Renewable and Sustainable Energy Reviews 39 (2014), 748-764

5. http://wysokienapiecie.pl/oze/2307-w-2017-wiecejpradu-z-wegla-mniej-z-oze [date of access: 12.01.2017]

6. https://www.ure.gov.pl/ [date of access : 18.01.2018]

7. http://wysokienapiecie.pl/oze/2586-cena-zielonychcertyfikatow-tge-zl-mwh [date of access: 12.01.2017]
8. http://gramwzielone.pl/trendy/26003/najwieksza-whistorii-nadpodaz-zielonych-certyfikatow [date of access: 12.01.2017]

9. G.M.J. Herbert, S Iniyan., D. Amutha, A review of technical issues on the development of wind farms. Renewable and Sustainable Energy Reviews 32 (2014), 619-641

10. http://wysokienapiecie.pl/prawo-energetyczne/1393msz-ostro-krytykuje-ustawe-o-odleglosci-wiatrakow [date of access: 12.01.2017]

11. http://inwestycjeliniowe.pl/farmy-wiatrowe-nowezasady-lokalizacji-elektrowni-wiatrowej/ [date of access: 12.01.2017]

12. https://www.money.pl/gospodarka/wiadomosci/arty kul/energetyka-wiatrowa-w-polsce-branza-walczyo,34,0,2136354.html [date of access: 12.01.2017]

13. http://wysokienapiecie.pl/prawo-energetyczne/1388ustawa-antywiatrakowa-dotknie-4-terytoriumpolski-i-nieruchomosci-o-wartosci-7-mld-zl [date of access: 12.01.2017]

14. http://wysokienapiecie.pl/oze/1384-sad-najwyzszyustawa-antywiatrakowa-moze-byc-niekonstytucyjna [date of access: 12.01.2017]

15. http://wysokienapiecie.pl/prawo-energetyczne/1341biuro-analiz-sejmu-ustawa-antywiatrakowa-zagrozirealizacji-celu-oze-na-2020-r [date of access: 12.01.2017]

16. J.S. González, R. Lacal-Arántegui, A review of regulatory framework for wind energy in European Union countries: Current state and expected developments. Renewable and Sustainable Energy Reviews 56 (2016),588-602

17. Wykonanie celu OZE 2020. Analiza stanu obecnego i prognoza, red. Schnell R. SOLIVAN Adwokaci i Radcy Prawni

18. Wind Energy in Europe: Outlook to 2020. Wind Europe, 2017 Brussels

19. Wind Energy in Europe: Scenarios for 2030. Wind Europe, 2017 Brussels

20. The state of wind energy in Poland in 2016. PWEA 2017

21. R. McKenna, S. Hollnaicher, P. Ostman v.d. Leye, W. Fichtner, Cost-potentials for large onshore wind turbines in Europe. Energy 83 (2015), 217-229

22. B. Igliński, A. Iglińska, G. Koziński, M. Skrzatek, R. Buczkowski, Wind energy in Poland - history, current state, surveys, Renewable Energy Sources Act, SWOT analysis. Renewable and Sustainable Energy Reviews 64 (2016), 19-33

23. S. Ruggiero, V. Varho, P. Rikkonen, Transition to distributed energy generation in Finland: prospects and barriers. Energy Policy 86 (2015), 433-443

24. M. Garcia-Alvarez, L. Cabeza-Garcia, I. Soares, Analysis of the promotion of onshore wind energy in the EU: Feed-in tariff or renewable portfolio standard? Renewable Energy 111 (2017), 256-264 
25. A. Brzezińska-Rawa, J. Goździewicz-Biechońska, Recent developments in the wind energy sector in Poland. Renewable and Sustainable Energy Reviews 38 (2014), 79-87

26. F. Hvelplund, P.A. Østergaard, N.I. Meyer, Incentives and barriers for wind power expansion and system integartion in Denmark. Energy Policy 107 (2017), 573-584

27. J. Nordensvärd, F. Urban, The stuttering energy transition in Germany: wind energy policy and feedin tariff lock-in. Energy Policy 82 (2015), 156-165

28. L. Ho, Wind energy in Malaysia : past, present and future. Renewable and Sustainable Energy Reviews 53 (2016), 279-295

29. A. Darmani, E. Niesten, M. Hekkert, Characteristics of investors in onshore wind power in Sweden Environmental Innovation and Societal Transitions 24 (2017), 67-82

30. S. Höltinger, B. Salak, T. Schauppenlehrer, P. Scherhaufer, J. Schmidt, Austria's wind energy potential - a participatory modeling approach to assess socio-political and market acceptance. Energy Policy 98 (2016), 49-61

31. Elefheriadis I.M. and Anagnostopoulou E.A., Identyfying barriers in the diffusion of renewable energy sources. Energy Policy 80 (2015), 153-164

32. Z. Khan, A.A. Khan, Current barriers to renewavle energy development in Trinidad and Tobago. Startegic Planning for Energy and the Environment 36 (2017), 8-23

33. C. Ghisetti, S. Mancinelli, M. Mazzanti, M. Zoli, Financial barriers and environmental innovations: evidence from EU manufacturing firms. Climate Policy 17 (2017), 131-147

34. A. Tzouvelekis, A study of the potential for small wind turbines in Greece: current market status, barriers to growth and support policy options. Master thesis in Faculty of Technology, Policy and Management in Delft University of Technology

35. N. Mercer, G. Saba, A. Klinke, "Wind is not an issue for government": Barriers to wind energy development in Newfoundland and Labrador, Canada. Energy Policy 108 (2017), 673-683

36. S. Sen, S. Ganguly, Opportunities, barriers and issues with renewable Energy development - a discussion. Renewable and Sustainable Energy Reviews 69 (2017), 1170-1181

37. V. Mytilinou, A.J. Kolios, G. Di Lorenzo, A comparative multidisciplinary policy review in wind energy developments in Europe. International Journal of Sustainable Energy 36 (2017), 754-774

38. M. Krzywonos, J. Skudlarski, A. Kupczyk, J. Wojdalski, K. Tucki., 2015, Przem.Chem. 2015; $94 / 12$

39. A.N. Commin, M.W.H. Davidson, N. Largey, P.P.J. Gaffney, D.W. Braidwood, S.W. Gibb, J. McClatchey, Spatial smoothing of onshore wind: implications for strategic development in Scotland. Energy Policy 109 (2017), 36-48

40. https://www.wind-watch.org/documents/europeansetbacks-minimum-distance-between-wind-turbinesand-habitations/ [date of acess: 18.01.2018]

41. Legal opinion on the compliance of the act on wind farm investments with the community law, Warsaw 2016

42. D. Angelopoulos, R. Brückmann, F. Jirouš, I. Konstantinavičiūtè, P. Noothout, J. Psarras, L. Tesnière, B. Breitschopf, Risks and cost of capital for onshore wind energy investments in EU countries. Energy \& Environment 2016, 27 (1), 82104[http://journals.sagepub.com/doi/pdf/10.1177/09 $58305 \times 16638573]$ 